Bull. Chem. Soc. Ethiop. 2004, 18(1), 17-28.

ISSN 1011-3924

Printed in Ethiopia

(c) 2004 Chemical Society of Ethiopia

\title{
SYNTHESIS AND CHARACTERIZATION OF MONOMERIC MANGANESE(II) AND COBALT(III) COMPLEXES OF THE HEXADENTATE AMINE LIGAND N,N,N',N'-TETRAKIS(2-PYRIDYLMETHYL)ETHANE-1,2-DIAMINE, $\mathrm{C}_{26} \mathrm{H}_{28} \mathrm{~N}_{6}$ (tpen)
}

\author{
Jørgen Glerup ${ }^{1}$, Patricia A. Goodson ${ }^{2}$, Derek J. Hodgson ${ }^{3 *}$ \\ Nicolai Jensen ${ }^{1}$ and Kirsten Michelsen ${ }^{1}$ \\ ${ }^{1}$ Department of Chemistry, University of Copenhagen, Universitetsparken 5, DK-2100, \\ Copenhagen $\varnothing$, Denmark \\ ${ }^{2}$ Department of Chemistry, University of Wyoming, Laramie, Wyoming 82071, USA \\ ${ }^{3}$ President, Indiana University of Pennsylvania, Indiana, Pennsylvania 15705, USA
}

(Received July 26, 2002; revised December 22, 2003)

\begin{abstract}
The syntheses and characterization of complexes of manganese(II) and cobalt(III) with the potentially hexadentate ligand $\mathrm{N}, \mathrm{N}, \mathrm{N}^{\prime}, \mathrm{N}^{\prime}$-tetrakis(2-pyridylmethyl)ethane-1,2-diamine, $\mathrm{C}_{26} \mathrm{H}_{28} \mathrm{~N}_{6}$ (tpen), are described. The monomeric manganese(II) complex $\left[\mathrm{Mn}\left(\mathrm{C}_{26} \mathrm{H}_{28} \mathrm{~N}_{6}\right)\left(\mathrm{H}_{2} \mathrm{O}\right)\right]\left(\mathrm{ClO}_{4}\right)_{2}$ (1) crystallizes in the monoclinic space group $\mathrm{C} 2 / \mathrm{c}$ with 4 formula units in a cell of dimensions $a=$ 15.080(1) $\AA, b=10.101(1) \AA, c=19.426(2) \AA$ and $\beta=94.61(1)^{\circ}$. The structure has been refined to a final value of the conventional $R$-factor of 0.0401 based on 2586 observed independent reflections. The geometry at the manganese center is seven-coordinate, and is best described as a capped trigonal pyramid with the water molecule forming the cap and the six nitrogen atoms of the tpen ligand occupying the pyramidal sites. The manganese atom and the water molecule lie on a crystallographic twofold axis. The related cobalt(III) complex, $\left[\mathrm{Co}\left(\mathrm{C}_{26} \mathrm{H}_{28} \mathrm{~N}_{6}\right)\right]\left(\mathrm{C} 1 \mathrm{O}_{4}\right)_{3}(4)$ crystallizes in the monoclinic space group $P 2_{1} / n$ with 4 formula units in a cell of dimensions $a=9.829(2) \AA, b$ $=18.364(4) \AA, c=18.128(4) \AA$ and $\beta=93.64(3)^{\circ}$. The structure has been refined to a final value of the conventional $R$-factor of 0.0526 based on 3574 observed independent reflections. The complex is approximately octahedral, the coordination being provided by the six nitrogen atoms of the tpen ligand. The EPR spectrum of 1 diluted into the corresponding Cd(II) host has been simulated with the parameters $\mathrm{g}=2.00, \mathrm{~A}=0.0080 \mathrm{~cm}^{-1}, \mathrm{D}=0.116 \mathrm{~cm}^{-1}$, and $\mathrm{E}=0.0013 \mathrm{~cm}^{-1}$. The small value of $\mathrm{E} / \mathrm{D}$ is consistent with the observed symmetry of the complex.
\end{abstract}

KEY WORDS: Monomeric manganese(II) complex, Monomeric cobalt(III) complex, Hexadentate ligand, $\mathrm{N}, \mathrm{N}, \mathrm{N}^{\prime}, \mathrm{N}^{\prime}$-tetrakis(2-pyridylmethyl)ethane-1,2-diamine

\section{INTRODUCTION}

There remains considerable interest in the establishment of quantitative and/or qualitative relationships between molecular structure, on the one hand, and magnetic susceptibility and EPR spectroscopy on the other. In order to analyze the EPR spectra of crystalline complexes, it is generally true that the measurement requires the availability of a diamagnetic host with similar structure, size, and metallic sites as found in the paramagnetic complex. In the case of manganese(II) complexes, we have had some success in preparing and characterizing zinc(II) or cadmium(II) analogues for this purpose. We have, however, found that interpretation of the spectra requires the complete structural characterization of both the paramagnetic and diamagnetic species because of the existence of several possible geometric isomers [1]. We have earlier synthesized and structurally characterized six-coordinate complexes of manganese(II) with the ligands 2-pyridylmethylamine [2] and bis(2-pyridylmethylamine) [1]. The compounds

*Corresponding author. Phone: 724 357-2200. Fax: 724 357-3060. E-mail: dhodgson@iup.edu 
and their zinc and cadmium analogous were synthesized with the purpose of measuring and trying to interpret the EPR spectra of the manganese compounds dissolved in solid diamagnetic hosts. While our previous work was confined to complexes with tridentate or tetradentate ligands, recently we extended these concepts to complexes with asymmetric bidentate ligands [3]. We have now further extended the series of ligands to include the hexadentate amine ligand $\mathrm{N}, \mathrm{N}, \mathrm{N}^{\prime}, \mathrm{N}^{\prime}$-tetrakis(2-pyridylmethyl)ethane-1,2-diamine, $\mathrm{C}_{26} \mathrm{H}_{28} \mathrm{~N}_{6}$ (tpen). We have previously shown [4] that tpen is capable of binding to all six sites of a normal pseudo-octadehral complex, as in $[\mathrm{Cr}(\text { tpen })]^{3+}$. In the same series, however, we also demonstrated that in the presence of other ligands, stable six-coordinate complexes are formed in which tpen coordinates to the metal through only five nitrogen donors [4].

We here report the syntheses and characterization of manganese(II) and cobalt(III) complexes of tpen, along with the analogous zinc(II) and cadmium(II) complexes for use as potential diamagnetic hosts.

\section{EXPERIMENTAL}

Syntheses. N,N,N',N'-tetrakis(2-pyridylmethyl)ethane-1,2-diamine (tpen) was synthesized by a method found in the literature [5].

Aqua [N,N,N',N'-tetrakis(2-pyridylmethyl)ethane-1,2-diamine] manganese(II) perchlorate, $\left[\mathrm{Mn}^{\mathrm{II}}\left(\mathrm{C}_{26} \mathrm{H}_{28} \mathrm{~N}_{6}\right)\left(\mathrm{H}_{2} \mathrm{O}\right)\right]\left(\mathrm{ClO}_{4}\right)_{2}$. (1). The ligand tpen $(0.235 \mathrm{~g}, 0.553 \mathrm{mmol})$ was dissolved in a mixture of water $(8 \mathrm{~mL})$ and a small amount of acetic acid $(5$ drops, $4 \mathrm{M})$. When nitrogen had been bubbled through the solution for $10 \mathrm{~min}$, manganese(II) chloride tetrahydrate $(0.109 \mathrm{~g}$, $0.551 \mathrm{mmol}$ ) was added. This caused a change in $\mathrm{pH}$ from 7 to $3-4$. Therefore, the $\mathrm{pH}$ was adjusted to 6.5-7 with a few drops of a solution of sodium hydroxide $(2 \mathrm{M})$. During this process the nitrogen flow was continued. The solution was then left in a stoppered flask. After a few days solid sodium perchlorate was added. A whitish powder was precipitated. The compound was filtered and washed with a solution of sodium perchlorate $(1 \mathrm{M})$ and with ethanol $(96 \%)$. Yield: $0.330 \mathrm{~g}(86 \%)$. Anal. calcd. for $\left[\mathrm{Mn}\left(\mathrm{C}_{26} \mathrm{H}_{28} \mathrm{~N}_{6}\right)\left(\mathrm{H}_{2} \mathrm{O}\right)\right]\left(\mathrm{ClO}_{4}\right)_{2}: \mathrm{C}, 44.84 ; \mathrm{N}, 12.07 ; \mathrm{H}$, $4.34 ; \mathrm{Cl}, 10.18 \%$. Found: C, 44.59; N, 12.04; H, 4.29; Cl, $10.22 \%$.

[N,N,N',N'-tetrakis(2-pyridylmethyl)ethane-1,2-diamine] zinc(II) perchlorate, [ $\left.\mathrm{Zn}\left(\mathrm{C}_{26} \mathrm{H}_{28} \mathrm{~N}_{6}\right)\right]$ $\left(\mathrm{ClO}_{4}\right)_{2}(2)$. This complex was synthesized exactly as the complex with manganese(II) (1) but from anhydrous zinc chloride instead of manganese chloride tetrahydrate. Also, it was not necessary to use nitrogen. Yield: $83 \%$. Anal. calcd. for $\left[\mathrm{Zn}\left(\mathrm{C}_{26} \mathrm{H}_{28} \mathrm{~N}_{6}\right)\right]\left(\mathrm{ClO}_{4}\right)_{2}: \mathrm{C}, 45.34 ; \mathrm{N}$, $12.20 ; \mathrm{H}, 4.10 ; \mathrm{Cl}, 10.29 \%$. Found: C, 45.02; N, 11.99; H, 4.21; Cl, 10.38\%.

Aqua [N,N,N',N'-tetrakis(2-pyridylmethyl)ethane-1,2-diamine $]$ cadmium(II) perchlorate, $\left[\mathrm{Cd}\left(\mathrm{C}_{26} \mathrm{H}_{28} \mathrm{~N}_{6}\right)\left(\mathrm{H}_{2} \mathrm{O}\right)\right]\left(\mathrm{ClO}_{4}\right)_{2}(3)$. This complex was synthesized exactly as the corresponding complex with manganese(II) (1) but from cadmium chloride monohydrate instead of manganese chloride tetrahydrate. Also, nitrogen was omitted. Yield: 81\%. Anal. calcd. for $\left[\mathrm{Cd}\left(\mathrm{C}_{26} \mathrm{H}_{28} \mathrm{~N}_{6}\right)\left(\mathrm{H}_{2} \mathrm{O}\right)\right]\left(\mathrm{ClO}_{4}\right)_{2}: \mathrm{C}, 41.42 ; \mathrm{N}, 11.15 ; \mathrm{H}, 4.01 ; \mathrm{Cl}, 9.41 \%$. Found: $\mathrm{C}, 42.01 ; \mathrm{N} 11.29$; $\mathrm{H}, 3.97 ; \mathrm{Cl}, 9.58 \%$.

[N,N,N',N'-tetrakis(2-pyridylmethyl)ethane-1,2-diamine] cobalt(III) perchlorate, $\left[\mathrm{Co}\left(\mathrm{C}_{26} \mathrm{H}_{28} \mathrm{~N}_{6}\right)\right]\left(\mathrm{ClO}_{4}\right)_{3}(4)$. This complex was synthesized in a manner entirely analogous to that used for the corresponding chromium(III) complex [4]. 
Analyses. Carbon, nitrogen, hydrogen and chlorine analyses were performed at the microanalytical laboratory using standard methods.

Physical measurements. EPR spectra were recorded at several temperatures down to liquid helium temperature on a Bruker ESP 300 spectrometer operating at a frequency of $9.38 \mathrm{GHz}$ (X-band) with magnetic field modulation of $100 \mathrm{kHz}$, modulation amplitude of $5 \mathrm{G}$ and microwave power of $10 \mathrm{~mW}$. Samples were examined as solids.

$X$-Ray structure determinations. The structures of the complexes $\mathbf{1}$ and $\mathbf{4}$ were determined at room temperature on a Siemens P3 diffractometer equipped with a molybdenum tube $\lambda\left(\mathrm{K} \alpha_{1}=\right.$ $0.70926 \AA$ A $\mathrm{K} \alpha 2=0.71354 \AA$ ) and a graphite monochromator. The data were corrected for absorption using semi-empirical techniques via psi scans. The structures were solved by direct methods and refined by full-matrix least-squares techniques using structure solution programs from the SHELXTL system [6]. Crystal data and experimental parameters are listed in Table 1.

Table 1. Crystallographic and data collection parameters.

\begin{tabular}{|c|c|c|}
\hline Complex & 1 & 4 \\
\hline Formula & $\mathrm{C}_{26} \mathrm{H}_{30} \mathrm{Cl}_{2} \mathrm{MnN}_{6} \mathrm{O}_{9}$ & $\mathrm{C}_{26} \mathrm{H}_{28} \mathrm{C}_{13} \mathrm{CoN}_{6} \mathrm{O}_{12}$ \\
\hline System & Monoclinic & Monoclinic \\
\hline Space group & $\mathrm{C} 2 / \mathrm{c}$ & $P 2{ }_{l} / n$ \\
\hline$a(\AA)$ & $15.080(1)$ & $9.829(2)$ \\
\hline $\mathrm{b}(\AA)$ & $10.101(1)$ & $18.364(4)$ \\
\hline $\mathrm{c}(\AA)$ & $19.426(2)$ & $18.128(4)$ \\
\hline$\beta$ (deg.) & $94.61(1)$ & $93.64(3)$ \\
\hline $\mathrm{V}\left(\AA^{3}\right)$ & $2949.5(5)$ & $3265(1)$ \\
\hline $\mathrm{Z}$ & 4 & 4 \\
\hline$\mu\left(\mathrm{mm}^{-1}\right)$ & 0.692 & 0.841 \\
\hline Index ranges & $\begin{array}{l}-17 \leq \mathrm{h} \leq 0 \\
-12 \leq \mathrm{k} \leq 0 \\
-23 \leq \ell \leq 23\end{array}$ & $\begin{array}{l}0 \leq \mathrm{h} \leq 11 \\
0 \leq \mathrm{k} \leq 21 \\
-21 \leq \ell \leq 21\end{array}$ \\
\hline $2 \theta$ range (deg.) & $4.2 \leq 2 \theta \leq 50.0$ & $4.0 \leq 2 \theta \leq 50.0$ \\
\hline No. of reflections & 3265 & 5750 \\
\hline Observed reflections & 2318 & 3574 \\
\hline $\mathrm{R}$ (observed data) & 0.0401 & 0.0526 \\
\hline $\mathrm{R}_{\mathrm{w}}$ (observed data) & $0.1043^{*}$ & 0.059 \\
\hline $\mathrm{R}$ (all data) & 0.0442 & 0.0964 \\
\hline $\mathrm{R}_{\mathrm{w}}$ (all data) & $0.1090^{*}$ & 0.0681 \\
\hline Goodness of fit & 1.055 & 1.3 \\
\hline
\end{tabular}

"Rw is calculated on $\mathrm{F}^{2}$ for complex $\mathbf{1}$.

Aqua [N,N,N',N'-tetrakis(2-pyridylmethyl)ethane-1,2-diamine] manganese(II) perchlorate, $\left[\mathrm{Mn}^{I I}\left(\mathrm{C}_{26} \mathrm{H}_{28} \mathrm{~N}_{6}\right)\left(\mathrm{H}_{2} \mathrm{O}\right)\right]\left(\mathrm{ClO}_{4}\right)_{2}(\mathbf{1})$. The complex crystallizes in the centrosymmetric monoclinic space group $C 2 / c$ with four molecules in the cell. A total of 3265 independent reflections was measured in the range $4.2^{\circ} \leq 2 \theta \leq 50^{\circ}$, with the data gathered having $-17 \leq \mathrm{h} \leq 0,-12 \leq \mathrm{k} \leq 0$, $-23 \leq \ell \leq 23$. The non-hydrogen atoms were refined anisotropically. Hydrogen atoms attached to carbon atoms were included in calculated positions using a riding model and refined with isotropic displacement coefficients set to 1.2 times that of the atom to which they were attached. 
The final values of the conventional and weighted $R$ factors were $R 1=0.0401$ (on $\mathrm{F}$ ), and wR2 $=0.1043\left(\right.$ on $\mathrm{F}^{2}$ ) based on 2318 observed independent intensities with $\mathrm{F} \geq 4.0 \sigma(\mathrm{F})$. The positional parameters are listed in Table 2 .

Table 2. Atomic coordinates $\left[\mathrm{x} 10^{4}\right]$ and equivalent isotropic displacement parameters $\left[\AA^{2} \times 10^{3}\right]$ for $\mathbf{1}$.

\begin{tabular}{|l|l|l|l|l|}
\hline Atom & $\mathrm{x}$ & $\mathrm{y}$ & $\mathrm{z}$ & $\mathrm{U}(\mathrm{eq})$ \\
\hline $\mathrm{Mn}(1)$ & 0 & $-4454(1)$ & 2500 & $34(1)$ \\
$\mathrm{O}(1)$ & 0 & $-2218(3)$ & 2500 & $51(1)$ \\
$\mathrm{N}(1)$ & $-775(1)$ & $-6336(2)$ & $2900(1)$ & $44(1)$ \\
$\mathrm{N}(2)$ & $-482(1)$ & $-4071(2)$ & $3669(1)$ & $42(1)$ \\
$\mathrm{N}(3)$ & $-1388(1)$ & $-4490(2)$ & $1925(1)$ & $39(1)$ \\
$\mathrm{C}(1)$ & $-495(2)$ & $-7527(3)$ & $2534(2)$ & $56(1)$ \\
$\mathrm{C}(2)$ & $-546(2)$ & $-6456(3)$ & $3652(1)$ & $48(1)$ \\
$\mathrm{C}(3)$ & $-718(2)$ & $-5164(3)$ & $4001(1)$ & $42(1)$ \\
$\mathrm{C}(4)$ & $-1093(2)$ & $-5118(3)$ & $4623(1)$ & $54(1)$ \\
$\mathrm{C}(5)$ & $-1222(2)$ & $-3911(4)$ & $4928(2)$ & $61(1)$ \\
$\mathrm{C}(6)$ & $-953(2)$ & $-2792(3)$ & $4609(2)$ & $60(1)$ \\
$\mathrm{C}(7)$ & $-598(2)$ & $-2909(3)$ & $3980(1)$ & $50(1)$ \\
$\mathrm{C}(8)$ & $-1741(2)$ & $-6147(3)$ & $2766(1)$ & $55(1)$ \\
$\mathrm{C}(9)$ & $-1976(2)$ & $-5387(3)$ & $2113(1)$ & $43(1)$ \\
$\mathrm{C}(10)$ & $-2796(2)$ & $-5551(3)$ & $1750(2)$ & $56(1)$ \\
$\mathrm{C}(11)$ & $-3027(2)$ & $-4763(3)$ & $1189(1)$ & $55(1)$ \\
$\mathrm{C}(12)$ & $-2434(2)$ & $-3829(3)$ & $1000(1)$ & $47(1)$ \\
$\mathrm{C}(13)$ & $-1624(2)$ & $-3728(3)$ & $1375(1)$ & $43(1)$ \\
$\mathrm{Cl}(1)$ & $1181(1)$ & $51(1)$ & $3902(1)$ & $52(1)$ \\
$\mathrm{O}(2)$ & $1689(2)$ & $1220(3)$ & $3919(2)$ & $101(1)$ \\
$\mathrm{O}(3)$ & $288(2)$ & $390(3)$ & $3967(2)$ & $115(1)$ \\
$\mathrm{O}(4)$ & $1489(2)$ & $-830(3)$ & $4426(1)$ & $107(1)$ \\
$\mathrm{O}(5)$ & $1227(2)$ & $-591(2)$ & $3248(1)$ & $79(1)$ \\
$\mathrm{U}(\mathrm{eq})$ & & & \\
\hline
\end{tabular}

$\mathrm{U}(\mathrm{eq})$ is defined as one third of the trace of the orthogonalized $\mathrm{U}_{\mathrm{ij}}$ tensor.

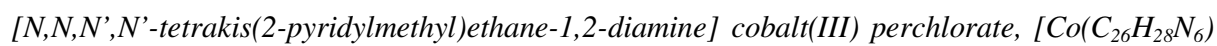
$\left(\mathrm{ClO}_{4}\right)_{3}$ (4). The complex is isomorphous with the corresponding chromium(III) complex reported earlier [4], crystallizing in the centrosymmetric monoclinic space group $P 2_{l} / n$ with four molecules in the cell. A total of 5750 independent reflections was measured in the range $4^{\circ} \leq 2 \theta$ $\leq 50^{\circ}$, with the data gathered having $0 \leq \mathrm{h} \leq 11,0 \leq \mathrm{k} \leq 21,-21 \leq \ell \leq 21$. The refinement was performed as above for (1). Three of the perchlorate oxygen atoms attached to $\mathrm{Cl}(2)$ were each disordered between two positions labeled A and B, with percent occupancies of 69.6 and 30.4, respectively. In the same manner, oxygen atoms attached to $\mathrm{Cl}(3)$ were disordered, with percent occupancies of 64.6 and 35.4 for the positions labeled A and B, respectively. The final values of the conventional and weighted $R$ factors (on $\mathrm{F}$ ) were $R 1=0.0526$, and $w R 2=0.0590$, based on 3574 observed independent intensities with $\mathrm{F} \geq 4.0 \sigma(\mathrm{F})$. The positional parameters are listed in Table 3. 
Table 3. Atomic coordinates $\left[\mathrm{x} 10^{4}\right]$ and equivalent isotropic displacement parameters $\left[\AA^{2} \times 10^{3}\right]$ for 4 .

\begin{tabular}{|c|c|c|c|c|}
\hline Atom & $\mathrm{x}$ & $\mathrm{y}$ & $\mathrm{z}$ & $\mathrm{U}(\mathrm{eq})$ \\
\hline Co & 1099(1) & $2107(1)$ & $7808(1)$ & $31(1)$ \\
\hline $\mathrm{N}(1)$ & 2349(3) & $2725(2)$ & 8401(2) & $37(1)$ \\
\hline $\mathrm{N}(2)$ & 1093(3) & $2869(2)$ & $7066(2)$ & $38(1)$ \\
\hline $\mathrm{N}(3)$ & $-249(3)$ & $2703(2)$ & $8273(2)$ & $42(1)$ \\
\hline $\mathrm{N}(4)$ & $-401(3)$ & $1555(2)$ & $7335(2)$ & $44(1)$ \\
\hline $\mathrm{N}(5)$ & 2151(3) & 1471(2) & 7201(2) & $32(1)$ \\
\hline $\mathrm{N}(6)$ & 1188(3) & $1334(2)$ & $8548(2)$ & $36(1)$ \\
\hline $\mathrm{C}(1)$ & $3629(4)$ & $2906(2)$ & $8254(2)$ & $47(1)$ \\
\hline $\mathrm{C}(2)$ & 4371(5) & $3399(3)$ & $8698(3)$ & $71(2)$ \\
\hline $\mathrm{C}(3)$ & $3785(7)$ & $3698(3)$ & $9287(3)$ & $85(2)$ \\
\hline $\mathrm{C}(4)$ & $2468(6)$ & $3528(3)$ & $9433(3)$ & $66(2)$ \\
\hline $\mathrm{C}(5)$ & $1766(5)$ & $3036(2)$ & $8981(2)$ & $46(1)$ \\
\hline $\mathrm{C}(6)$ & $300(5)$ & $2830(3)$ & $9048(2)$ & $52(1)$ \\
\hline $\mathrm{C}(7)$ & 1882(4) & $2898(3)$ & $6486(2)$ & $52(1)$ \\
\hline $\mathrm{C}(8)$ & $1796(6)$ & $3464(3)$ & 5991(3) & $75(2)$ \\
\hline $\mathrm{C}(9)$ & $901(6)$ & $4019(3)$ & $6088(3)$ & $89(2)$ \\
\hline $\mathrm{C}(10)$ & $132(5)$ & $4012(3)$ & $6695(3)$ & $69(2)$ \\
\hline $\mathrm{C}(11)$ & $267(4)$ & $3433(2)$ & $7180(2)$ & $44(1)$ \\
\hline $\mathrm{C}(12)$ & $-459(5)$ & $3415(2)$ & $7875(2)$ & $50(1)$ \\
\hline $\mathrm{C}(13)$ & $-1554(4)$ & $2284(3)$ & $8212(3)$ & $59(2)$ \\
\hline $\mathrm{C}(14)$ & $-1663(4)$ & 1995(3) & $7424(3)$ & $61(2)$ \\
\hline $\mathrm{C}(15)$ & $3464(4)$ & $1268(2)$ & 7314(2) & $38(1)$ \\
\hline $\mathrm{C}(16)$ & 4087(5) & $834(3)$ & $6814(3)$ & $56(1)$ \\
\hline $\mathrm{C}(17)$ & $3342(6)$ & 594(3) & $6189(3)$ & $66(2)$ \\
\hline $\mathrm{C}(18)$ & 1990(6) & $776(3)$ & $6090(3)$ & $67(2)$ \\
\hline $\mathrm{C}(19)$ & $1408(4)$ & $1214(2)$ & $6595(2)$ & $45(1)$ \\
\hline $\mathrm{C}(20)$ & $-57(4)$ & $1447(3)$ & $6554(2)$ & $54(1)$ \\
\hline $\mathrm{C}(21)$ & $2078(5)$ & 1291(3) & $9154(2)$ & $47(1)$ \\
\hline $\mathrm{C}(22)$ & $2122(5)$ & $677(3)$ & $9597(3)$ & $62(2)$ \\
\hline $\mathrm{C}(23)$ & $1260(6)$ & $108(3)$ & $9426(3)$ & $72(2)$ \\
\hline $\mathrm{C}(24)$ & $374(5)$ & $143(3)$ & $8819(3)$ & $64(2)$ \\
\hline $\mathrm{C}(25)$ & $358(4)$ & $765(2)$ & $8383(3)$ & $44(1)$ \\
\hline$C(26)$ & $-527(5)$ & $820(2)$ & $7698(3)$ & $56(1)$ \\
\hline C1(1) & 1184(1) & $4008(1)$ & $3961(1)$ & $53(1)$ \\
\hline $\mathrm{O}(1)$ & $2515(3)$ & $3956(2)$ & $4308(2)$ & $81(1)$ \\
\hline $\mathrm{O}(2)$ & $389(4)$ & $4490(2)$ & $4356(2)$ & $109(2)$ \\
\hline $\mathrm{O}(3)$ & $1272(4)$ & $4270(2)$ & $3218(2)$ & $97(1)$ \\
\hline $\mathrm{O}(4)$ & $587(4)$ & $3324(2)$ & $3930(3)$ & $120(2)$ \\
\hline $\mathrm{Cl}(2)$ & 7431(1) & $-268(1)$ & $5973(1)$ & $53(1)$ \\
\hline $\mathrm{O}(5 \mathrm{~A})$ & $6240(9)$ & $-25(6)$ & $5595(5)$ & $138(5)$ \\
\hline $\mathrm{O}(6 \mathrm{~A})$ & $7389(9)$ & $-127(6)$ & $6708(4)$ & $106(4)$ \\
\hline $\mathrm{O}(7 \mathrm{~A})$ & $7435(8)$ & $-1048(3)$ & $5840(4)$ & $91(3)$ \\
\hline $\mathrm{O}(8)$ & $8567(4)$ & $-25(2)$ & $5612(2)$ & $97(1)$ \\
\hline $\mathrm{O}(5 \mathrm{~B})$ & $8012(17)$ & $-551(10)$ & $6663(10)$ & $73(6)$ \\
\hline $\mathrm{O}(6 \mathrm{~B})$ & $6393(23)$ & $-606(12)$ & $5667(9)$ & $104(10)$ \\
\hline $\mathrm{O}(7 \mathrm{~B})$ & $7053(16)$ & $504(9)$ & $6194(12)$ & $104(8)$ \\
\hline $\mathrm{Cl}(3)$ & $920(1)$ & $2046(1)$ & $1143(1)$ & $66(1)$ \\
\hline $\mathrm{O}(9 \mathrm{~A})$ & $1715(18)$ & $1469(6)$ & $1493(13)$ & $137(8)$ \\
\hline $\mathrm{O}(10 \mathrm{~A})$ & $336(14)$ & $2414(10)$ & $1704(8)$ & 101(6) \\
\hline $\mathrm{O}(11 \mathrm{~A})$ & $1837(22)$ & $2468(12)$ & $785(9)$ & $165(10)$ \\
\hline
\end{tabular}

Bull. Chem. Soc. Ethiop. 2004, 18(1) 


\begin{tabular}{|l|l|l|l|l|}
\hline $\mathrm{O}(12)$ & $38(4)$ & $1685(3)$ & $633(2)$ & $115(2)$ \\
\hline $\mathrm{O}(9 \mathrm{~B})$ & $223(24)$ & $2707(9)$ & $1140(32)$ & $227(16)$ \\
\hline $\mathrm{O}(10 \mathrm{~B})$ & $2184(21)$ & $2184(21)$ & $936(16)$ & $163(16)$ \\
\hline $\mathrm{O}(11 \mathrm{~B})$ & $850(34)$ & $1817(26)$ & $1825(10)$ & $191(17)$ \\
\hline
\end{tabular}

$\mathrm{U}(\mathrm{eq})$ is defined as one third of the trace of the orthogonalized $\mathrm{U}_{\mathrm{ij}}$ tensor.

\section{RESULTS AND DISCUSSIONS}

Description of the structures

Aqua [N,N,N',N'-tetrakis(2-pyridylmethyl)ethane-1,2-diamine] manganese(II) perchlorate, $\left[\mathrm{Mn}^{I I}\left(\mathrm{C}_{26} \mathrm{H}_{28} \mathrm{~N}_{6}\right)\left(\mathrm{H}_{2} \mathrm{O}\right)\right]\left(\mathrm{ClO}_{4}\right)_{2} \quad(\mathbf{l})$. The structure consists of monomeric $\left[\mathrm{Mn}^{11}\left(\mathrm{C}_{26} \mathrm{H}_{28} \mathrm{~N}_{6}\right)\left(\mathrm{H}_{2} \mathrm{O}\right)\right]^{2+}$ cations and perchlorate anions that are well separated from each other. A view of the cation is provided in Figure 1. Principal bond lengths and angles are listed in Table 4 . With four molecules per cell in the centrosymmetric monoclinic space group $\mathrm{C} 2 / \mathrm{c}$, the complex is constrained to exhibit crystallographic symmetry. In the present case, the manganese atom and the coordinated water molecule lie on a crystallographic two-fold axis. The geometry at manganese is seven coordinate, and is best described as a capped trigonal pyramid with the water molecule forming the cap and the six nitrogen atoms of the tpen ligand occupying the pyramidal sites. A six-coordinate trigonal prism may be viewed as consisting of two parallel trigonal faces, one above and the other below the central metal. Consequently, if viewed perpendicular to the trigonal faces, there are three rectangular faces, each joining pairs of atoms in the two trigonal faces. In the present structure, the (approximately) trigonal faces are formed by atoms $\mathrm{N}(1), \mathrm{N}(2), \mathrm{N}(3)$ and by $\mathrm{N}(1 \mathrm{~A}), \mathrm{N}(2 \mathrm{~A}), \mathrm{N}(3 \mathrm{~A})$. The approximately rectangular faces are formed by $\mathrm{N}(2), \mathrm{N}(3), \mathrm{N}(2 \mathrm{~A}) \mathrm{N}(3 \mathrm{~A})$, by $\mathrm{N}(1) \mathrm{N}(1 \mathrm{~A}), \mathrm{N}(3 \mathrm{~A}), \mathrm{N}(2)$, and by $\mathrm{N}(1), \mathrm{N}(1 \mathrm{~A})$, $\mathrm{N}(2 \mathrm{~A}), \mathrm{N}(3)$. A seven-coordinate capped trigonal prism may be described as a trigonal prism in which the seventh bond passes through the middle of one of the rectangular faces of the trigonal prism. In the present structure, this seventh coordination site (or cap) is occupied by $\mathrm{O}(1)$, the $\mathrm{Mn}-\mathrm{O}(1)$ bond passing through the approximately rectangular face $\mathrm{N}(2), \mathrm{N}(3), \mathrm{N}(2 \mathrm{~A}) \mathrm{N}(3 \mathrm{~A})$. The inner coordination sphere around manganese is shown in Figure 2, the view being chosen so that this rectangular face is approximately horizontal in the figure and the cap is shown to sit beneath this face. The crystallographic twofold axis is vertical in this figure, passing through atoms $\mathrm{Mn}$ and $\mathrm{O}(1)$ and relating atoms $\mathrm{N}(1), \mathrm{N}(2), \mathrm{N}(3)$ to $\mathrm{N}(1 \mathrm{~A}), \mathrm{N}(2 \mathrm{~A}), \mathrm{N}(3 \mathrm{~A})$, respectively.

The isomer isolated here has the four pyridine nitrogen atoms forming the approximately square base of the coordination polyhedron. It is noteworthy that in the six-coordinate, pseudooctahedral complex $[\mathrm{Cr}(\text { tpen })]^{3+}[4]$, and in the cobalt(III) analogue $[\mathrm{Co}(\text { tpen })]^{3+}$ described below, the pyridine nitrogen atoms do not assume this geometry since the amine nitrogen atoms cannot accommodate trans positions in an octahedral structure. It is also noteworthy that in the complexes $[\mathrm{Cr}(\mathrm{tpen})(\mathrm{OH})]^{2+}$ and $\left[\mathrm{Cr}(\mathrm{tpen})\left(\mathrm{OCOCH}_{3}\right)\right]^{2+}$, in which the tpen ligand coordinates through only five nitrogen atoms, and in $\left[\mathrm{Cr}(\operatorname{tpen})(\mathrm{OH})_{2}\right]^{+}$where only four tpen nitrogen atoms are coordinated, it is one or two of the pyridine nitrogen atoms that are uncoordinated [4].

Seven-coordinate species are more commonly associated with second- and third-row transition metal complexes than with first-row metals [7]. However, while certainly relatively uncommon, seven-coordination in manganese(II) chemistry is not unknown. The classic example, in some ways parallel to our present case, is that of the ethylenediaminetetraacetate (edta) complex, in which the hexacoordinate edta ligand occupies six sites and a water molecule occupies the seventh [8]. In the more recent example of $\mathrm{Mn}\left(\mathrm{pyo}_{3}\right.$ tren), $\left[\mathrm{Mn}\left(\mathrm{C}_{24} \mathrm{H}_{27} \mathrm{~N}_{7} \mathrm{O}_{3}\right]^{2+}\right.$, manganese(II) is coordinated to a heptadentate ligand via three oxygen and four nitrogen atoms [9]. The "parent" six-coordinate trigonal prismatic structure is also more readily accommodated by the $d^{5} \mathrm{Mn}(\mathrm{II})$ ion than by other first row transition metal ions [10]. 


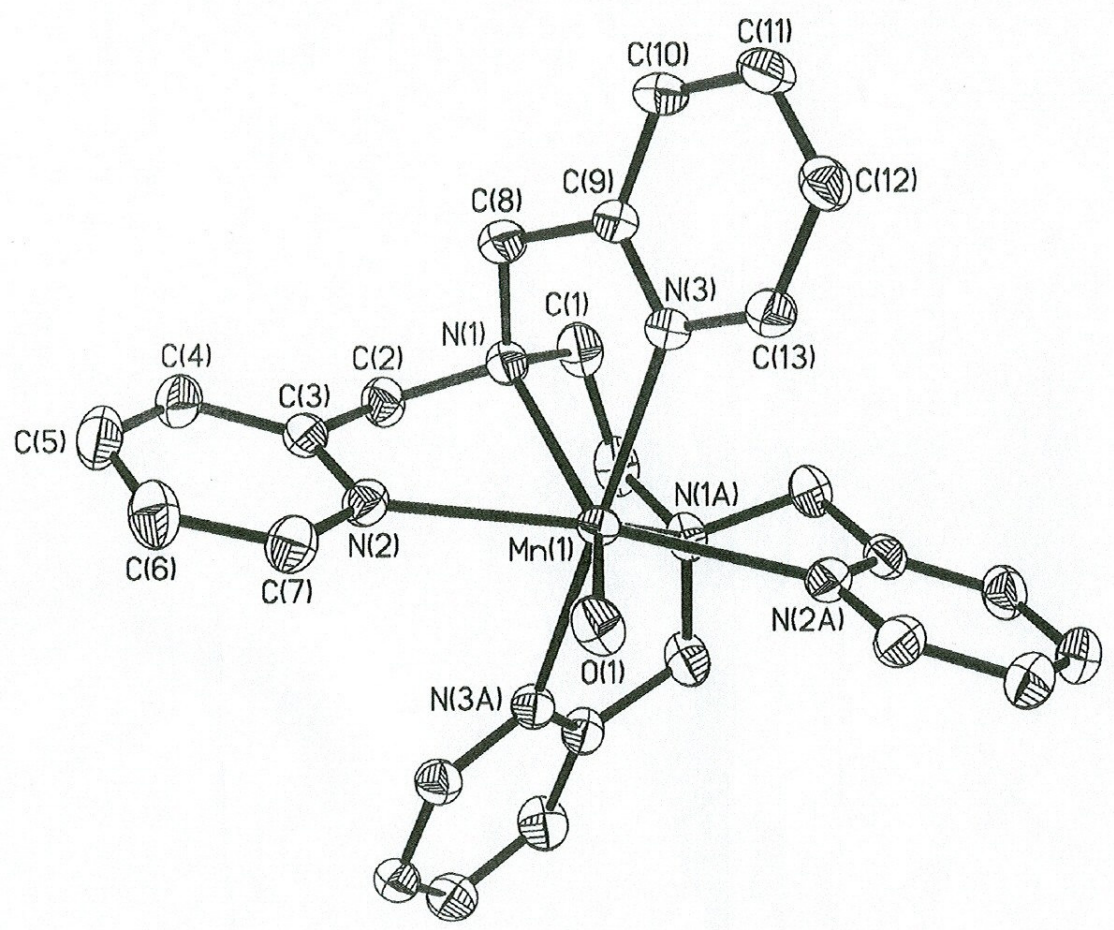

Figure 1. View or the $\left[\mathrm{Mn}^{\mathrm{II}}\left(\mathrm{C}_{26} \mathrm{H}_{28} \mathrm{~N}_{6}\right)\left(\mathrm{H}_{2} \mathrm{O}\right)\right]^{2+}$ cation in the crystals of (1).

Table 4. Principal bond Lengths $[\AA]$ and angles $\left[{ }^{\circ}\right]$ for $\mathbf{1}$

$$
\text { Bond lengths }
$$

$\begin{array}{llll}\mathrm{Mn}(1)-\mathrm{O}(1) & 2.258(3) & \mathrm{Mn}(1)-\mathrm{N}(1) & 2.393(2) \\ \mathrm{Mn}(1)-\mathrm{N}(2) & 2.472(2) & \mathrm{Mn}(1)-\mathrm{N}(3) & 2.292(2)\end{array}$

Bond angles

$\begin{array}{lclc}\mathrm{O}(1)-\mathrm{Mn}(1)-\mathrm{N}(1) & 142.59(5) & \mathrm{O}(1)-\mathrm{Mn}(1)-\mathrm{N}(2) & 80.99(5) \\ \mathrm{O}(1)-\mathrm{Mn}(1)-\mathrm{N}(3) & 90.92(5) & \mathrm{N}(1)-\mathrm{Mn}(1)-\mathrm{N}(1 \mathrm{~A}) & 74.83(10) \\ \mathrm{N}(1)-\mathrm{Mn}(1)-\mathrm{N}(2) & 68.82(7) & \mathrm{N}(1)-\mathrm{Mn}(1)-\mathrm{N}(2 \mathrm{~A}) & 127.61(7) \\ \mathrm{N}(1)-\mathrm{Mn}(1)-\mathrm{N}(3) & 72.23(7) & \mathrm{N}(1)-\mathrm{Mn}(1)-\mathrm{N}(3 \mathrm{~A}) & 106.24(7) \\ \mathrm{N}(2)-\mathrm{Mn}(1)-\mathrm{N}(2 \mathrm{~A}) & 161.97(10) & \mathrm{N}(2)-\mathrm{Mn}(1)-\mathrm{N}(3) & 97.22(3) \\ \mathrm{N}(2)-\mathrm{Mn}(1)-\mathrm{N}(3 \mathrm{~A}) & 83.07(6) & \mathrm{N}(3)-\mathrm{Mn}(1)-\mathrm{N}(3 \mathrm{~A}) & 178.17(10)\end{array}$

Atoms labelled $\mathrm{N}(1 \mathrm{~A})$ etc. are related to the parent atoms $\mathrm{N}(1)$ etc. by the symmetry transformation $-\mathrm{x}, \mathrm{y}, 1 / 2-\mathrm{z}$. 


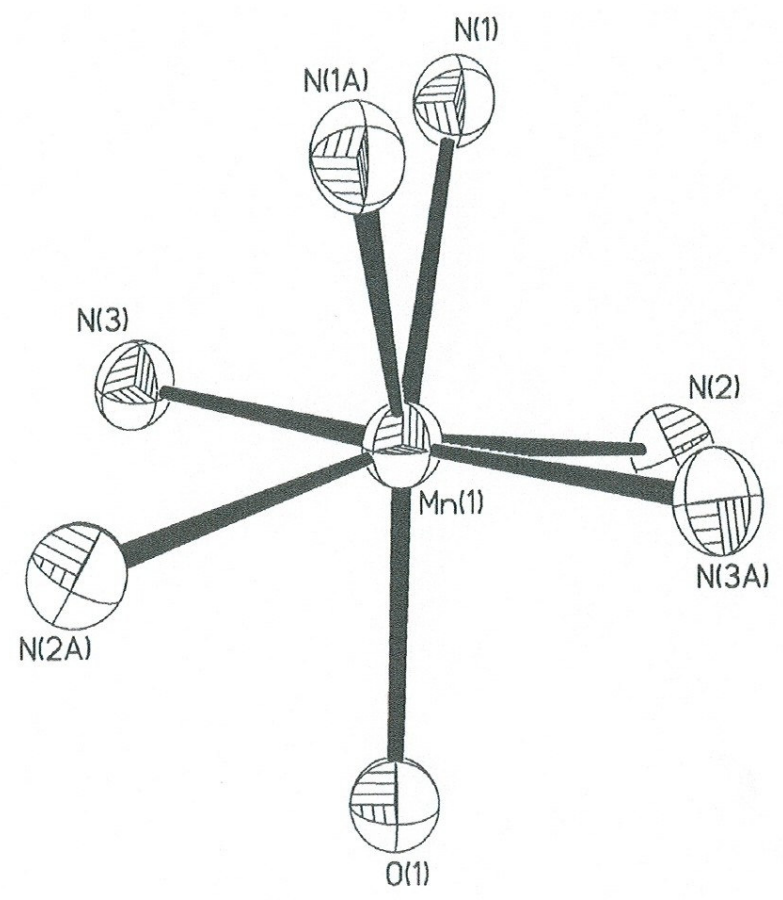

Figure 2. The inner coordination sphere around manganese in the $\left[\mathrm{Mn}^{\mathrm{II}}\left(\mathrm{C}_{26} \mathrm{H}_{28} \mathrm{~N}_{6}\right)\left(\mathrm{H}_{2} \mathrm{O}\right)\right]^{2+}$ cation. The crystallographic twofold axis is vertical in this figure, passing through atoms $\mathrm{Mn}$ and $\mathrm{O}(1)$ and relating one trigonal face [atoms $\mathrm{N}(1), \mathrm{N}(2), \mathrm{N}(3)$ ] to the other $[\mathrm{N}(1 \mathrm{~A}), \mathrm{N}(2 \mathrm{~A}), \mathrm{N}(3 \mathrm{~A})]$.

The bond lengths and bond angles at the manganese center are worthy of some discussion in this relatively unusual coordination geometry. The three independent $\mathrm{Mn}-\mathrm{N}$ distances fall in the range 2.292 (2) $\AA$ to 2.470 (2) $\AA$; perhaps surprisingly, the Mn-N(1) distance of 2.393 (2) $\AA$ involving the amine nitrogen atom lies in between the values for the pyridine nitrogen atoms. Since the amine nitrogen atoms are apical while the pyridine nitrogen atoms occupy the tetragonal face, there is clearly no reasonable distinction that can be drawn concerning these bond lengths on the basis of their coordination mode or position. These lengths may be compared with $\mathrm{Mn}(\mathrm{II})-\mathrm{N}$ (amine) distances of 2.286 (3) - 2.293 (3) $\AA$ and Mn(II)-N(pyridine) distances of 2.252 (4) - 2.256 (4) $\AA$ found in recently reported six-coordinate complexes with multidentate ligands [11]. The Mn-O distance of 2.258 (3) $\AA$ is comparable to other values reported for $\mathrm{Mn}(\mathrm{II})-\mathrm{OH}_{2}$ and $\mathrm{Mn}$ (II)-OR complexes [12, 13]. Distances similar to these have been observed in axially-elongated $\mathrm{Mn}(\mathrm{III})-\mathrm{OH}_{2}$ and $\mathrm{Mn}(\mathrm{III})-\mathrm{OR}$ complexes [14], but as anticipated, these distances are all larger than those of approximately $2.0 \AA$ reported for analogous $\mathrm{Mn}(\mathrm{IV})$ systems $[15,16]$.

The bond angles at manganese can be compared with those found in the classic example of the capped trigonal prism, $\left[\mathrm{Mo}(\mathrm{CNR})_{7}\right]^{2+}[17]$. The idealized structure has $\mathrm{C}_{2 \mathrm{v}}$ symmetry, and while the crystallographic symmetry here is only $\mathrm{C}_{2}$, examination of Figure 2 demonstrates the approximate $\mathrm{C}_{2 \mathrm{v}}$ site symmetry at $\mathrm{Mn}$. The nominally trans base angles $\mathrm{N}(3)-\mathrm{Mn}-\mathrm{N}(3 \mathrm{~A})$ and $\mathrm{N}(2)-\mathrm{Mn}-\mathrm{N}(2 \mathrm{~A})$ of $178.2(1)^{\circ}$ and $162.0(1)^{\circ}$, respectively, demonstrate that the $\mathrm{Mn}$ atom is more 
nearly in the base plane than is the case in $\left[\mathrm{Mo}(\mathrm{CNR})_{7}\right]^{2+}$ where these angles have an average value of $164.0^{\circ}$ [17].

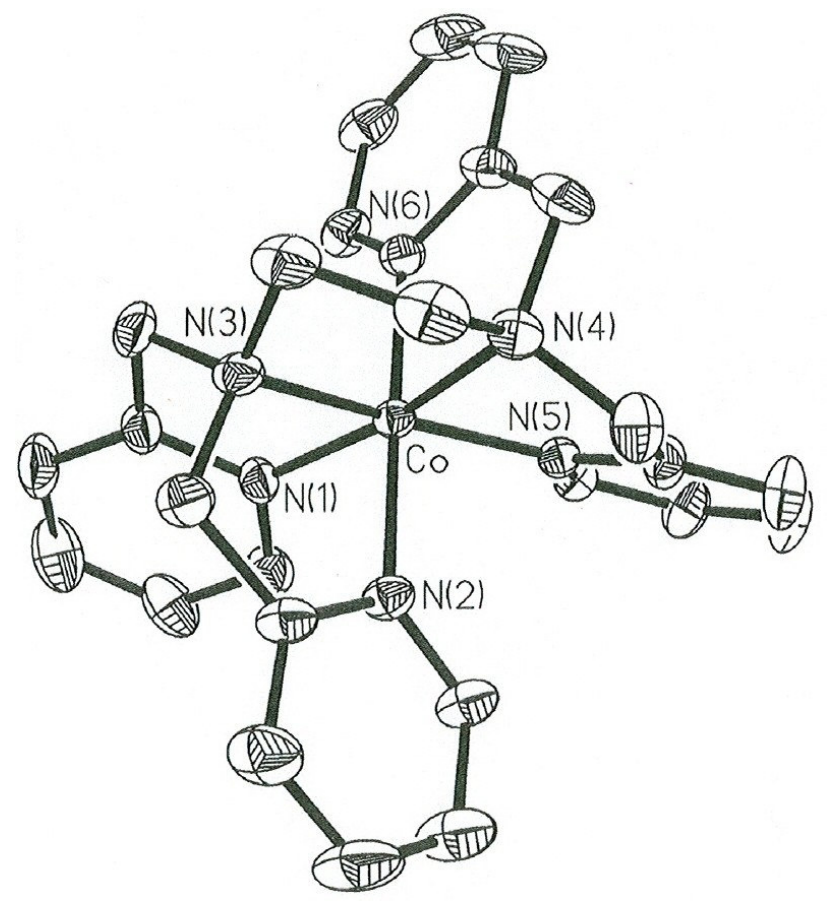

Figure 3. View of the $[\mathrm{Co}(\text { tpen })]^{3+}$ cation in the crystals of the perchlorate salt (4). Unlabeled atoms are carbon.

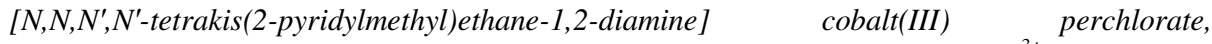
$\left[\mathrm{Co}\left(\mathrm{C}_{26} \mathrm{H}_{28} \mathrm{~N}_{6}\right)\right]\left(\mathrm{ClO}_{4}\right)_{3}$ (4). The structure consists of monomeric [Co(tpen) $]^{3+}$ cations and perchlorate anions. A view of the cation is given in Figure 3, and the principal bond lengths and angles are listed in Table 5. The structure of the cation here is substantially similar to that of the chromium(III) analogue, $[\mathrm{Cr}(\mathrm{tpen})]^{3+}$ reported earlier [4]. The complex is pseudo-octahedral, the coordination being provided by the six nitrogen atoms of the tpen ligand. The isomer isolated here is again the one with the amine nitrogen atoms $\mathrm{N}(3)$ and $\mathrm{N}(4)$ cis. Thus, necessarily, the nitrogen atoms associated with either end of the substituted diamine $[\mathrm{N}(1), \mathrm{N}(2), \mathrm{N}(3)$ and $\mathrm{N}(4)$, $\mathrm{N}(5), \mathrm{N}(6)]$ are facial. The Co-N(amine) distances of 1.941(3) $\AA$ and 1.944 (3) $\AA$ [average, 1.943 (2) $\AA$ ] are not significantly different from the Co-N(pyridine) bond lengths of 1.946 (3) $\AA$ to 1.951 (3) $\AA$ [average, 1.949 (2) $\AA$ ]. As anticipated, the Co-N lengths found here are approximately $0.10 \AA$ shorter than the $\mathrm{Cr}-\mathrm{N}$ distances of 2.039 (4) $\AA$ to 2.063 (5) $\AA$ in the chromium(III) analogue [4]. The $\mathrm{N}-\mathrm{Co}-\mathrm{N}$ bond angles demonstrate the distortions from octahedral geometry resulting from the steric constraints of the ligand. Thus, the five-membered chelate rings all give rise to acute cis angles, while the open cis angles $\mathrm{N}(1)-\mathrm{Co}-\mathrm{N}(6)$ and $\mathrm{N}(2)-$ $\mathrm{Co}-\mathrm{N}(5)$ are obtuse. The trans angles fall in the relatively narrow range of 168.7 (2) ${ }^{\circ}$ to 177.5 $(1)^{\circ}$. Two of the three perchlorate anions in the structure are disordered. They were satisfactorily 
fitted to a model in which two unequally occupied sets of three oxygen atom positions share a common $\mathrm{C} 1-\mathrm{O}$ bond $[\mathrm{Cl}(2)-\mathrm{O}(8)$ and $\mathrm{Cl}(3)-\mathrm{O}(12)]$, giving rise to two approximate tetrahedra which are rotated approximately $60^{\circ}$ from each other. This kind of disorder has been observed in several previous structure determinations $[4,11]$.

Table 5. Principal bond lengths $[\AA]$ and angles $\left[{ }^{\circ}\right]$ for $\mathbf{4}$.

\begin{tabular}{|c|c|c|c|}
\hline \multicolumn{4}{|c|}{ Bond lengths } \\
\hline Co-N(l) & $1.946(3)$ & Co-N(2) & $1.941(3)$ \\
\hline Co-N(3) & $1.951(3)$ & Co-N(4) & $1.944(3)$ \\
\hline $\mathrm{Co}-\mathrm{N}(5)$ & $1.947(3)$ & Co-N(6) & $1.950(3)$ \\
\hline \multicolumn{4}{|c|}{ Bond angles } \\
\hline $\mathrm{N}(1)-\mathrm{Co}-\mathrm{N}(2)$ & $86.32(14)$ & $\mathrm{N}(1)-\mathrm{Co}-\mathrm{N}(3)$ & $81.8(2)$ \\
\hline $\mathrm{N}(1)-\mathrm{Co}-\mathrm{N}(4)$ & $169.4(2)$ & $\mathrm{N}(1)-\mathrm{Co}-\mathrm{N}(5)$ & $108.81(14)$ \\
\hline N(1)-Co-N(6) & $92.63(14)$ & $\mathrm{N}(2)-\mathrm{Co}-\mathrm{N}(3)$ & $85.59(14)$ \\
\hline $\mathrm{N}(2)-\mathrm{Co}-\mathrm{N}(4)$ & $95.8(2)$ & $\mathrm{N}(2)-\mathrm{Co}-\mathrm{N}(5)$ & $91.07(14)$ \\
\hline $\mathrm{N}(2)-\mathrm{Co}-\mathrm{N}(6)$ & $177.50(14)$ & $\mathrm{N}(3)-\mathrm{Co}-\mathrm{N}(4)$ & $88.1(2)$ \\
\hline $\mathrm{N}(3)-\mathrm{Co}-\mathrm{N}(5)$ & $168.7(2)$ & $\mathrm{N}(3)-\mathrm{Co}-\mathrm{N}(6)$ & $96.51(14)$ \\
\hline $\mathrm{N}(4)-\mathrm{Co}-\mathrm{N}(5)$ & $81.52(14)$ & $\mathrm{N}(4)-\mathrm{Co}-\mathrm{N}(6)$ & $85.6(2)$ \\
\hline $\mathrm{N}(5)-\mathrm{Co}-\mathrm{N}(6)$ & $87.12(13)$ & & \\
\hline
\end{tabular}

EPR spectroscopy. The EPR powder spectra of the $\mathrm{Mn}^{\mathrm{II}}$ complex doped in the similar $\mathrm{Zn}{ }^{\mathrm{II}}$ and $\mathrm{Cd}^{\mathrm{II}}$ complexes were measured. The spectrum of $\mathrm{Mn}^{\mathrm{II}}$ doped in the $\mathrm{Cd}^{\mathrm{II}}$ is easy to simulate while the spectrum of $\mathrm{Mn}^{\mathrm{II}}$ doped in the $\mathrm{Zn}^{\mathrm{II}}$ complex could not be reproduced with the accuracy expected. By comparing the relative sizes of the three metal ions in octahedral symmetry $\mathrm{Zn}^{\mathrm{II}}$ : $\mathrm{Mn}^{\mathrm{II}}: \mathrm{Cd}^{\mathrm{II}}=0.88: 0.97: 1.09$ [18], we can see that there is space enough for doping manganese in cadmium complexes but not in zinc complexes. The spectrum from the doping in zinc could be interpreted by assuming that the manganese complex was placed in several slightly different sites, because of the limited space. The EPR-spectra were simulated in order to understand the $\mathrm{Mn}^{\text {II }}$ spectra [1]. The energy matrix was generated for each orientation of the magnetic field relative to the molecular $\mathrm{z}$ axis. The energy matrix was calculated by means of the following Hamiltonian

$$
\hat{H}=g \mu_{B} \hat{H} \cdot \hat{S}+A \hat{S} \cdot \hat{I}+D\left[\hat{S}_{z}^{2}-1 / 3 S(S+1)\right]+E\left(\hat{S}_{x}^{2}-S_{y}^{2}\right)
$$

with $S=5 / 2$ and $I=5 / 2$. The resonance conditions for each transition were found by successive diagonalizations and iterations of the full energy matrix and the intensities were calculated from the eigenvectors. No selection rules were used so in all there was a search for 540 transitions for each orientation. The final spectrum was then a summation of all the calculated transitions where each transition was represented by a Lorentzian band shape. The EPR parameters were all extracted from the powder spectra.

In Figure 4 is shown the experimental and simulated spectra of the $\mathrm{Mn}^{\mathrm{II}}$ complex. The spectrum was simulated with the parameters $g=2.00, \mathrm{D}=0.116 \mathrm{~cm}^{-1} \mathrm{E}=0.0013 \mathrm{~cm}^{-1}$ and $\mathrm{A}=$ $0.0080 \mathrm{~cm}^{-1}$. During the simulation process it was realized that some lines around $0.8 \mathrm{~T}$ which had not been found should also be observable. These lines were then sought and found in the experimental spectrum. Above the spectra is given the resonance condition as function of the angle between the magnetic field and the molecular $\mathrm{z}$ axis. For simplicity this drawing has been simplified by setting the nuclear spin to zero. As can be seen the agreement between the simulated and the experimental spectrum is very convincing. 


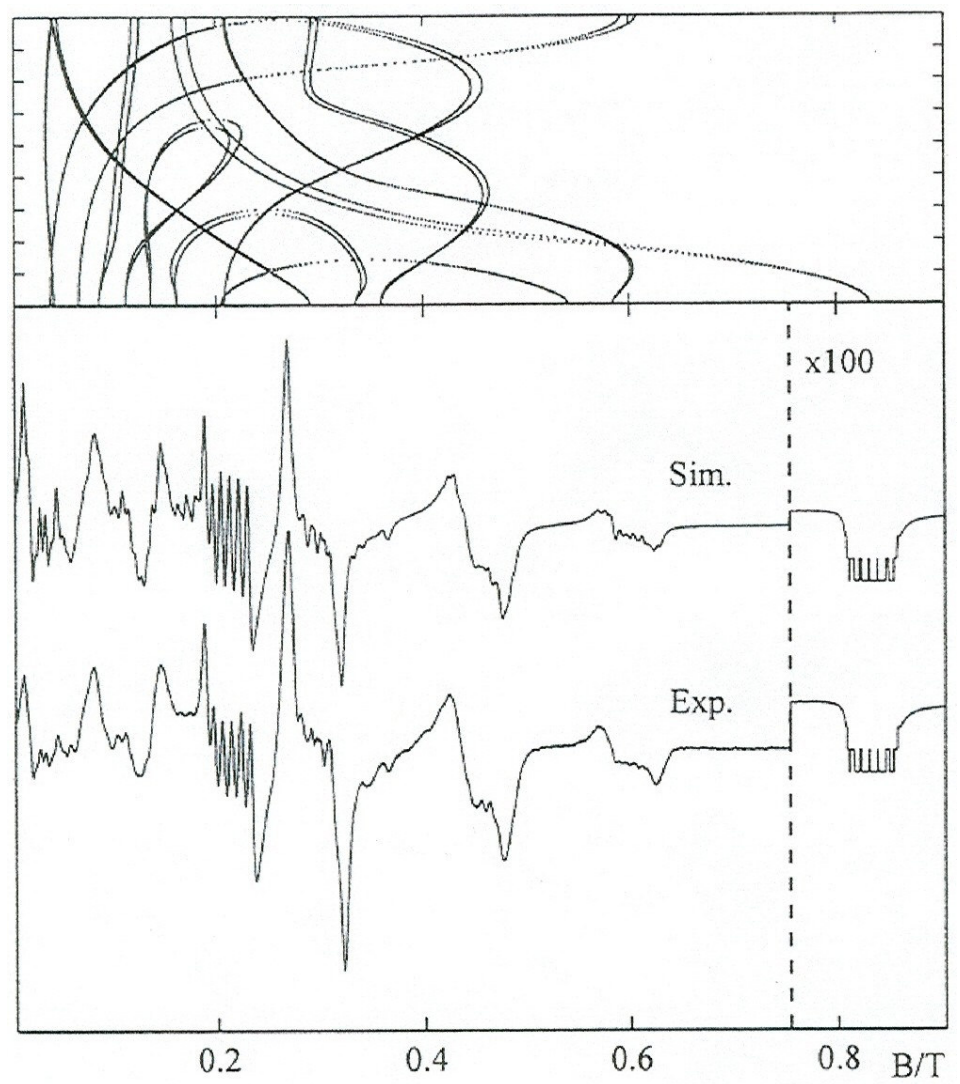

Figure 4. Experimental and simulated EPR spectra of $\left[\mathrm{Mntpen}\left(\mathrm{OH}_{2}\right)\right]\left(\mathrm{ClO}_{4}\right)_{2}(\mathbf{1})$ diluted in the analogous cadmium complex. For simplicity the nuclear spin has been set to zero.

\section{ACKNOWLEDGEMENTS}

This work was supported by the Scientific Affairs Division, North Atlantic Treaty Organization (NATO) through Grant No. CRG 910277.

Supplementary material. Tables of complete bond distances and angles, anisotropic displacement parameters $\left(\mathrm{U}_{\mathrm{ij}}\right)$ and hydrogen atom parameters, and listings of observed and calculated structure amplitudes for the complexes $\mathbf{1}$ and $\mathbf{4}$ are available from DJH.

\section{REFERENCES}

1. Glerup, J.; Goodson, P.A.; Hodgson, D.J.; Michelsen, K.; Nielsen, K.M.; Weihe, H. Inorg. Chem. 1992, 31, 4611.

2. Hodgson, D.J.; Michelsen, K.; Pedersen, E. Acta Chem. Scand. 1990, 44, 1002.

Bull. Chem. Soc. Ethiop. 2004, 18(1) 
3. Glerup, J.; Goodson, P.A.; Hodgson, D.J.; Michelsen, K.; Rychlewska, U. Bull. Chem. Soc. Ethiop. 2000, 14, 129.

4. Eriksen, J.; Goodson, P.A.; Hazell, A.; Hodgson, D.J.; Michelsen, K.; Mønsted, O.; Rasmussen, J.C.; Toftlund, H. Acta Chem. Scand.. 1999, 53, 1083.

5. Mandel, J.B.; Maricondi, C.; Douglas, B.E. Inorg. Chem. 1988, 27, 2990.

6. Sheldrick, G.M. SHELXTL Crystallographic System, Version 4.2/Iris, Siemens Analytical XRay Instruments; Madison, WI; 1991.

7. Xu, L.; Setyawati, I.A.; Pierreroy, J.; Pink, M.; Young, Jr., V.G.; Patrick, B.O.; Rettig, S.J.; Orvig, C. Inorg. Chem. 2000, 39, 5958.

8. Richards, S.; Pedersen, B.; Silverton, J.B.; Hoard, J.L. Inorg. Chem. 1964, 3, 27.

9. Gou, S.; You, X.; Yu, K.; Lu, J. Inorg. Chem. 1993, 32, 1883.

10. Arulsamy, N.; Glerup, J.; Hodgson, D.J. Inorg. Chem. 1994, 33, 3043.

11. Glerup, J.; Goodson, P.A.; Hodgson, D.J.; Michelsen, K. Inorg. Chem. 1995, 34, 6255.

12. Tanase, T.; Lippard, S.J. Inorg. Chem. 1995, 34, 4682.

13. Goodson, P.A.; Oki, A.R.; Hodgson, D.J. Inorg. Chim. Acta 1990, 177, 59, and references therein.

14. Oki, A.R.; Hodgson, D.J. Inorg. Chim. Acta 1990, 170, 65.

15. Sarneski, J.E.; Thorp, H.H.; Brudvig, G.W.; Crabtree, R.H.; Schulte, G.K. J. Am. Chem. Soc. 1990, 112, 7255; Auger, N.; Girerd, J.J.; Corbella, M.; Gleizes, A.; Zimmerman, J.L. J. Am. Chem. Soc. 1990, 112, 448.

16. Reddy, K.R.; Rajasekharan, M.V.; Arulsamy, N.; Hodgson, D.J. Inorg. Chem. 1996, 35, 2283.

17. Drew M.G.B. Progr. Inorg. Chem. 1977, 23, 67.

18. Cotton, F.A.; Wilkinson, G. Advanced Inorganic Chemistry, 5th ed., Wiley: New York; 1988; Table A4-1. 